\title{
Representing the Twenty-First Century Migrant Experience: Adam and Fleutiaux's Problematic Empathy
}

\author{
Marianne Bessy \\ Furman University \\ Mary Sloan Morris \\ Furman University
}

In recent years, the global public has become accustomed to images of overturned boats and of bodies washed up on shore, such as that of young Aylan Kurdi, found drowned on a beach in Turkey (Bloch). News coverages have consistently presented the effects of the European migrant crisis since its peak in 2015. Migrants ${ }^{1}$ have entered the European Union (EU) in astounding numbers, more than one and a half million in three years as of 2018 (Boghani). They come mostly from Syria to escape the ongoing civil war, Afghanistan and Iraq, as well as from sub-Saharan Africa, Iran, and Kosovo. Unstable states and poverty have driven these individuals to search for a better life in what has become the "biggest crisis of its kind since the aftermath of World War II" ("Europe's Migrant Crisis"). Yet, those who cross the Mediterranean successfully remain in distressing conditions as EU countries continue to struggle to effectively respond to this influx of migrants. The "fundamental failure to find European-wide agreements on immigration" (Reinisch 519) and the recent European political climate characterized by the increase of antimigrant discourse-supported, as Dominic Thomas points out, by "the process of insisting on the enduring nature of the danger or threat to the national community presented by clandestine/illegal/irregular migrants" (450-51) explain why the crisis is still at the forefront, even if current arrival numbers are now back to pre-2015 levels (Nossiter and Hicks).

France has long been a country of transit, especially for migrants striving to reach Great Britain. The influx of migrants started in Calais in the mid-1990s when the Channel Tunnel opened. By 1999, hundreds of individuals from Afghanistan, Iran, and Iraq were risking their lives each day attempting to enter

\footnotetext{
${ }^{1}$ Many terms - refugees, migrants, asylum seekers, clandestins, etc.- - have been used to refer to those displaced individuals affected by the migrant crisis. In this study, we will use the term "migrant" throughout for the same reasons as those explained by the BBC: "The BBC uses the term migrant to refer to all people on the move who have yet to [successfully] complete the legal process of claiming asylum. This group includes people fleeing war-torn countries such as Syria, who are likely to be granted refugee status, as well as people who are seeking jobs and better lives, who governments are likely to rule are economic migrants" ("Migrant Crisis").
} 
Great Britain through the Tunnel. In order to deal with this crisis, the Red Cross camp Sangatte was opened in 1999 near Calais with enough resources for 900 migrants but numbers quickly escalated to 2,000 ("Calais Migrant Camps"). The camp became a source of tension between France and the United Kingdom (UK) and French authorities were pressured into closing the camp in 2002, leaving thousands to their own devices in the area. Since then, several unofficial camps have sprung up, including the first "Jungle," which was demolished by the French authorities in 2009 (Collins). A new Jungle camp held more than 8,000 migrants when it was similarly bulldozed in 2016. Today, without any legal residential structure in place, those migrants who reach Calais find themselves in worse conditions than those of the Jungle while others end up in makeshift camps in the French capital.

How have French authors responded to this crisis? How do they portray such illegal migration trajectories within the metropolitan French space in their literary works? These are the overarching questions guiding this study. Until recently, in the French literary context, topics related to migration had been addressed primarily by authors who had immigrated to France (often from former French colonies, especially those in North Africa or Sub-Saharan Africa) or who were born in France of parents who had emigrated from these postcolonial sites. As Myriam Louviot has shown, the 1980s, with the development of what was then labelled "Beur" literature, have been held as "the decade of emergence in France of postcolonial writers dealing with issues of migrancy and/or immigration" (2). By the end of the twentieth century, migrant literature $^{2}$ had become a minor genre mostly confined to the production of postcolonial authors who, although many lived and wrote in France, were excluded from the category of "French literature" and labelled "Francophone." This artificial category, a literary ghetto of sorts, has been widely debated ${ }^{3}$

\footnotetext{
2 Since it emerged in the 1980s, a number of terms have been used in the Quebec literary context ("écriture migrante" or "littérature migrante") and in the French literary context ("littérature issue de l'immigration," "littérarture beur," or "littérature migrante") to label this genre (Pruteanu 21-22). While these terms were initially used to encapsulate the production of authors who were themselves migrants and who portrayed migrant trajectories in their writings, there have been calls to envision the writing of migration as a phenomenon separate from the author's origins and personal experiences (see Bessy and Khordoc, Mardorossian or Xavier for instance). In this study, we choose to use the term "migrant literature" in its broadest sense to refer to "all works that are produced in a time of migration or that can be said to reflect on migration" (Walkowitz 533).

3 Although criticized for some inherent problems - the prominent status of some of the signatories which weakened its claims to speak for marginalized authors, the use of literary prizes to assess the value of literary works, or a lacking representation of female authors - the 2007 manifesto Pour une "littérature-monde" en français (Le Bris et al.) questioned the use of the category of "Francophone" literature and criticized it as "a legacy of colonialism" (Louviot 4). Françoise Lionnet, in her criticism of the manifesto, has called for the use of "Francophonies," in the
} 
because, in part, it masks these authors' identities and groups them together without clear criteria beyond the use of the French language and their colonial heritage. In the later part of the twentieth century, their works explored themes that came to be known as the hallmark of migrant "Francophone" literature: cultural belonging, exile, displacement, return, split identities, Frenchness, or racism.

In 2018, Oana Sabo published a groundbreaking study titled The Migrant Canon in Twenty-First-Century France in which she examines the impact twentyfirst-century migration has had on French literature. In the introduction, she makes a claim that we use here to describe the scope of our study. Sabo explains that "[o]ne major development of post-2000 migrant literature is the emergence of French authors who write about migration" (27). Since the beginning of the twenty-first century, non-migrant French authors have depicted the trajectory of illegal migrants in novels, récits, short stories, poems, plays, essays, comic books, and young adult fiction. Even if the novel is without doubt the genre that is most often used by these authors to explore contemporary migrant themesnotable examples are Marie Redonnet's 2005 Diego, Laurent Gaudé's 2006 Eldorado, Éric-Emmanuel Schmitt's 2008 Ulysse from Bagdad, Delphine Coulin's 2011 Samba pour la France, Mathias Énard's 2012 Rue des voleurs, Carole Zalberg's 2014 Fen pour feu, or Hugo Boris's 2016 Police - it is worth stressing that this increase in interest for migrant trajectories on the part of non-migrant French authors spans a variety of genres (Sabo 5). For instance, in 2015-in the aftermath of the Lampedusa disaster of 2013 that resulted in the tragic deaths of 360 Eritrean, Somalian, and Ghanaian migrants (Ming)—Denis Heudré's collection of poems Bleu naufrage: élégie de Lampedusa, Maylis de Kerangal's essay à ce stade de la nuit, and Annelise Heurtier's young adult novel Refuges were published. Additionally, several of the aforementioned authors contributed to the anthology Bienvenue! 34 auteurs pour les réfugiés that same year, including Olivier Adam whose work we examine in this study (Adam et al.).

Sabo's claim about these authors' newfound interest in illegal migration echoes that of Étienne Achille who believes that, since 2006, there has been a "multiplication des textes publiés par des 'écrivains blancs' de renom proposant une réflexion explicite sur la France postcoloniale" (15-16) as well as that of Louviot who states that "[i]n recent years, the drama of migrants dying on Europe's doorstep has inspired many [...] French writers with no postcolonial or (im)migrant background" (6). Therefore, the current study will examine how two non-migrant French authors, Olivier Adam in À l'abri de rien and Pierrette Fleutiaux in Destiny, have handled the topic of illegal migration in their post-

plural, to open "up literature to new and productive understandings of universality in a decentered and multilingual world" (203). 
2000 works. Our goal is to demonstrate that there is an inherent ambivalence at the heart of how non-migrant French authors have approached this topic in recent years. While Adam's and Fleutiaux's texts aim to foster empathy toward the plight of migrants, they also feature complex altruistic motives that are far from selfless. After providing some information about each author and their respective work, we will first show how Adam and Fleutiaux strive to humanize migrants by creating an empathic discourse of care. We will then discuss how migrant characters are portrayed as passive objects of fascination, becoming pawn-like figures in the lives of Marie and Anne, the white female protagonists of each text. Finally, we will question these characters' altruism by analyzing how their own mental states overpower their empathic drives, thus bringing to light the questionable reasons why these two French women become consumed by the need to help migrants. Ultimately, we aim to critique the problematic empathy Adam and Fleutiaux have constructed and its ethical ramifications.

Adam is a renowned French author who was born in 1974 and grew up in the Parisian suburbs. His first novel, Je vais bien, ne t'en fais pas, which was published in 2000 and adapted for the cinema by Philippe Lioret, contributed to his early fame. Since then, he has authored a dozen novels as well as books for children. His works, which are routinely shortlisted for major awards, are particularly successful at juxtaposing an intimate look on personal lives with a criticism of French society (Busnel). In 2004, Adam received the Prix Goncourt de la nouvelle and the Prix des Éditeurs for his short-story collection Passer l'hiver. He is also an accomplished screenwriter. Not only did he collaborate with Lioret on the adaptation of Je vais bien, ne t'en fais pas, but he co-authored the screenplay for Welcome — a 2009 movie recounting the fate of a young Iraqi-Kurd migrant in Calais - as well as that of Maman est folle, the television adaptation of A l'abri de rien. This 2007 novel recounts the story of Marie, the first-person narrator, a depressed wife and mother, who recently lost her job as a cashier and is struggling to find direction in her monotonous life. As she battles a serious mental health relapse, her strained marriage, her lack of purpose, and the haunting memory of her sister's death send her into a search for meaning that materializes in her desperate attempt to help migrants gathered in her area. Although the city remains unnamed, it closely resembles Calais; it faces the North Sea and experiences an influx of migrants living in harrowing conditions as they wait for the unlikely chance of crossing over to Great Britain after the recent closing of a Red Cross camp reminiscent of Sangatte. Marie develops an all-consuming relationship with several migrants-Jallal, Drago, and Bechir among others - and with Isabelle, a local volunteer who has experienced similar losses as Marie's and who acts as a sort of volunteering mentor. While Marie seems to regain some mental stability thanks to this newfound cause, she ends up neglecting her family and her physical well-being. Nominated for the Prix 
Goncourt in 2007, awarded the Prix Roman France Télévision, the Prix du roman populiste and the Prix Amila Meckert, À l'abri de rien explores how a lower middle class French woman can be affected by the migrant crisis.

Pierrette Fleutiaux, born in 1941 in the Creuse département, started her literary career in 1975. She moved to New York in 1968 where she taught in a French high school, worked for the UN as a translator, and was an editor. Fleutiaux served as the vice president of the Société des gens de lettres between 2014 and 2017 (Mijola). At the time of her death in 2019, she was an accomplished author who had published over twenty literary texts, including novels, short-stories, and children's books (Geniès). She was awarded the Prix Goncourt de la nouvelle in 1985 for her short-story collection Métamorphoses de la reine — a feminist rewriting of Charles Perrault's tales-and the Prix Fémina in 1990 for her novel Nous sommes éternels. Her works focus primarily on themes related to friendship and mother/daughter/granddaughter relationships (de Larminat). Destiny, published in 2016, was the last work she authored. In this text, Fleutiaux introduces her reader to a story not unlike that of Adam's character Marie. Anne is a French woman of the "classe moyenne éduquée" (cover copy) who, on her way home from a shopping trip in anticipation of her granddaughter's birth, encounters Destiny, a pregnant Nigerian woman taking shelter in a Parisian metro station. Although the narration is in third person, the narrator is not omniscient and the narrative voice is focalized through Anne whose thoughts the reader has access to. Anne and Destiny quickly form a bond that introduces Anne to the logistics and difficulties of being an illegal migrant living in the French capital. Destiny gradually shares details of her long and traumatic journey to France, of the children she left behind and those she had along the way, and of the husband she is unsure she will see again. Anne and Destiny's relationship evolves into one resembling that of a mother and a daughter as Anne helps Destiny with her infant daughter Glory, her mental health, and multiple temporary relocations in the Paris area. Destiny was awarded the Prix Jules-Sandeau in 2016 and the Prix Reconnaissance--La Voix de la Paix in 2017.

A variety of criteria were used to choose $A$ l'abri de rien and Destiny for this study. Most importantly given the scope of our analysis, the selected authors had to be French nationals who had not-and whose ancestors had notimmigrated to France in recent history. They had to be, to use an admittedly contested expression, "Français de souche." Furthermore, because it seemed important to examine the ways in which these writers describe how the French national space handles the presence of migrants, the selected works had to portray migration trajectories that led migrant characters to France, whether or not France was their intended final destination. It was also decided to include one text published before ( $A$ l'abri de rien) and one text published after (Destiny)

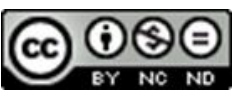


the Lampedusa disaster, unarguably one of the most memorable events in the early stages of the ongoing European migrant crisis. Additionally, the two texts feature "[t] he figure of the western European woman who empathizes with a clandestine immigrant and attempts to save him[,]" a trope Sabo underlined as characteristic of contemporary French migrant literature (25). The selected works also offer a social commentary on the reality of illegal migration in France and share similar themes of mental health issues and motherhood. Finally, for representability's sake, we strove to feature a text by a female and text by a male author whose works belonged to similar genre. Although Destiny's cover indicates that the text is a récit — while Á l'abri de rien is marketed as a noveland despite the fact that the book's premise is based on "a real-life encounter with an immigrant woman on the Paris Metro[]," we contend that they can be examined successfully in concert (Mijola). Fleutiaux herself, in a 2016 interview, blurred the lines between the récit and the novel when commenting on the degree of fictionality of her text by concluding: "ça devient presque un roman" ("Entretien"). Both Adam's and Fleutiaux's works can therefore be described as fictional narratives in prose.

In $\grave{A}$ l'abri de rien and in Destiny, the protagonists fall into roles of care-givers for the migrants they encounter. Marie stumbles across the tent where migrants gather for aid and accidentally starts volunteering. She serves food, distributes clothing, and treats wounds. Her relationship with individual migrants strengthens over the couple of weeks that span the timeframe of the novel. Marie accompanies Bechir to his court hearing and, when she learns he will be deported, tries to help him flee. Anne provides similar care to Destiny during the two years chronicled in the récit. She becomes a presence at Destiny's side in many life events, including the birth of her daughter Glory. She talks to social workers or doctors on Destiny's behalf and helps her through several mental breakdowns. Marie and Anne both give their clothes, money, and time to migrants with whom they communicate in English, ${ }^{5}$ except for Bechir who is fluent in French. Through the actions of their protagonists-who guide, assist, and provide moral support to the migrant characters-Adam and Fleutiaux create an empathic discourse of care in their texts. We base our analysis of this phenomenon on the following definition of "empathy": "an affective and

\footnotetext{
4 The récit genre is not clearly defined. Geoffrey Hartman explains that it is a "confessional narrative, a kind of dramatic monologue in prose" (7). Daniel Just stresses that "the récit as a category" is "elusive_-at once too broad and too specific. Meaning a "narrative" in general, récit has been used as an indefinite notion embracing many prose genre, to the point when it ceases to be clear if it does not coincide with narrative literature as such" (121).

${ }^{5}$ In $A$ l'abri de rien, there are a few instances when Marie and a migrant character exchange a few words in English. These English words are not italicized in Adam's text. In Destiny, Destiny expresses herself exclusively in English. These English sentences are italicized in Fleutiaux's text. We have not altered the original format when using quotes featuring English language.
} 
effective understanding of [the other's] experience" (Panaité 107). We also envision empathy as a "[m]irroring [of] what a person might be expected to feel" and as a "precursor to its semantic close relative, sympathy" (Keen 4). This focus on care and empathy in the authors' works is in line with Alexandre Gefen's study Réparer le monde: la littérature française face au XXI' siècle, which deals with the current turn to a therapeutical conception of literature. He believes that the focus on "individus fragiles," "oubliés de la grande histoire," and "communautés ravagées" has contributed to a "discours néo-humaniste" since the beginning of the twenty-first century (9). This current focus on an "éthique du care" (12) results in literary works that attempt to "corriger [1] es traumatismes de la mémoire individuelle ou du tissu sociétal" (11). When examining how this current empathic trend plays out in Adam and Fleutiaux, we notice the use of several individualizing and humanizing strategies.

Both texts resist presenting migrants as a homogenous group. Whereas Marie repeatedly notices the great number of migrants roaming the streets of her town $(23,64$, or 90$)$ and explains that they usually move in groups (86 or 91$)$, she refrains from describing them as an indistinguishable mass. During the first migrant encounter of the novel, as Marie drives by their rally point in front of the Monoprix supermarket, she rejects the erroneous blanket term used to refer to migrants and stresses their actual national identities: "Tout le monde les appelait les Kosovars, mais c'étaient surtout des Irakiens, des Iraniens, des Afghans, des Pakistanais, des Soudanais, des Kurdes" (23). Similarly, Anne attempts to bring attention to individual identities when she recounts seeing migrant boats on television: "Les gens sur ces barques ne sont pas des anonymes" (110). In both texts, the use of first names contributes to individualizing migrant characters. This is especially true of Fleutiaux's récit which is named after Destiny. Even on a paratextual level, the migrant character's trajectory thus initially takes center stage. Additionally, in $\dot{A}$ l'abri de rien, there is a shift from referring to migrants as "types" (23) and "ombres" (32) to using first names as Marie becomes more immersed in the migrant community. Consequently, the reader is not only confronted with the plight of migrants on a collective level but also with that of individual migrant characters named Jallal, Drago, Bechir, Abbas, or Destiny.

In their attempt to individualize migrant identities, Adam and Fleutiaux also emphasize their life stories. For instance, Marie learns that Bechir was a performer in Iran: "Il faisait de tout. Le clown, de la danse, du mime, du théâtre. Là-bas il avait une compagnie, le Théâtre de l'Oiseau" (139). She also discovers the terrible realities of his life leading up to his departure: "Il avait passé quatre ans en prison, on l'avait torturé, brûlé, électrocuté" (158). Anne tries to make sense of Destiny's past. As young as fourteen, she was repeatedly beaten, raped, 
and robbed while her family did nothing to help her: "They treated me like a ghost" (97). Trying to escape these circumstances, she had no other option but to move with men who exploited her: "I woke up in tears, I ate with tears, I slept with tears" (101). In both texts, the journeys taken to escape these harsh existences are filled with more horrors. Marie often wonders about the struggles migrants encounter: "À quoi ils pouvaient penser ces types? À ce qu'ils avaient traversé ? À ce qu'il leur faudrait endurer encore avant de gagner l'Angleterre ?" (114). Anne pieces together Destiny's journey_ “des années de tourments derrière elle, des années d'enfer" (17) — from her stories: crossing Niger and the Libyan desert, the attacks from bandits, and the shipwreck of the overcrowded "Zodiac" on the Mediterranean. Even when she finally makes it to Europe, and before she reaches Paris, Destiny is forced to become a prostitute in Italy although the smuggler who had sponsored her trip had promised that she would be hired as a hairdresser. There is therefore a deliberate effort on the authors' parts to convey to the reader the ordeals that these migrant characters have encountered prior to their arrival in France.

The accounts Marie and Anne provide of the daily lives of migrants once they are in France are also horrendous. Adam's text graphically describes violent police beatings (28 and 72), horrific unsheltered living conditions (219), and the brutal deaths of two migrants trying to clandestinely board trucks (115 and 187). Fleutiaux's text details Destiny's ordeal as she is thrown back on the streets immediately after giving birth to her baby and tries to clean herself in a Gare de Lyon bathroom (40). At this stage of the récit, her other children have been taken from her by the French authorities and she struggles to bring enough stability to her life in hopes of being reunited with her family. Marie stresses that all of the young men's belongings fit in plastic bags they have to constantly hold on to (60). Likewise, Anne summarizes how Destiny's life is reduced to a trash bag: "Encore une fois ses affaires jetées dans un sac-poubelle. Sa vie, un déchet de poubelle" (79). Adam and Fleutiaux go to great lengths to educate the reader about the logistical and administrative processes that migrants encounter. Destiny's existence becomes little more than a list of aid centers, official documents she relies on to remain in France, social workers, and the lodging helpline that assists her on several occasions. When Marie accompanies Bechir to his court hearing, she witnesses the unfairness of the system. Despite his ability to speak French and the scars that are proof of his endangerment in Iran, Bechir will be deported: "la décision était prise avant même qu’on arrive" (161). Both Adam - "ils ne devaient plus rien sentir, ni le froid ni les grêlons, ni la faim ni la fatigue" (32) —and Fleutiaux- "transportée, interrogée, déshabillée, examinée, rhabillée" (78) - use accumulation to convey the extreme precarity of the migrant character's life. 
While Marie and Anne experience conflicting emotions at times-Marie admits that she has "peurs mesquines" and "sentiments inavouables" (138)_, they are given social justice warrior roles and effectively serve as mouthpieces for Adam and Fleutiaux's criticisms of how illegal migrants are treated in France today. Anne dismisses French institutions as "défaillantes" (114) and rejects the claim that France is truly the country of human rights: "un petit bonhomme de pays qui ne peut plus se la jouer devant l'immense misère de l'humanité" (68). Marie questions the government's decision to close the Red Cross camp : "Je n'ai jamais compris pourquoi ils l'avaient fermé, ce camp. Les choses n'avaient fait qu'empirer" (23). She laments the criminalization of solidarity and conveys a less than flattering description of the Interior Minister, with his "sourire de reptile[,]" who reminds the reader of Nicolas Sarkozy (89). When she is taunted for "couch[er] avec des Kosovars" by her children's classmates, she empathetically absorbs some of the migrants' stigmata (127). In addition, the authors construct an environment that is particularly inhospitable. For example, in Adam, the ever-present wind is "une bête endormie" (27) and, in Fleutiaux, the Parisian "conurbation" is "monstrueuse" (150). Interestingly, this portrayal of the host city as a hostile environment is in line with previous studies which have shown "the ways in which the urban space alienates black immigrants" (Norrell 126). Finally, the impact of these living conditions on the migrant characters' mental and physical health is also criticized. Destiny suffers a severe breakdown (62-67) and eventually has to be treated at the Georges-Devereux center which specializes in ethnopsychiatry (134). In À l'abri de rien, oozing skin lesions due to injuries and lack of hygiene- “des rougeurs, des eczémas rosâtres, des brûlures anciennes, des cicatrices et d'autres marques encore, violines et inquiétantes" (111)—and teeth problems_- "leurs dents jaunies ou manquantes" (110) - appear recurrently in the text. With these vivid accounts, it is clear that the two authors strive, as Fleutiaux puts it, to show that "[1] e migrant est toujours au bord d'une catastrophe, d'une disparition, d'un glissement fatal" in order to create empathy for the living conditions of illegal migrants in France (70).

The treatment of migrant characters in both texts brings to light how dehumanizing their conditions are. Destiny is described as "un animal traqué" (49) and "un être non désiré" (179) while the migrants in Adam's text are "complètement humiliés" (109), "traqués comme des bêtes" (134), to the point where Marie is unable to tell if their limbs "appartenaient à des vivants ou des morts" (193)" and describes their eyes as "parfaitement inhumains" (71). However, there is a clear attempt to re-humanize these characters. The authors do so by stressing their moral qualities: Jallal's kindness is put to the forefront when he fixes Marie's tire during a rainstorm (38) and Destiny is described as a character with a strong moral compass (93). Adam also stresses the positive impact the caring actions of Marie and Isabelle, who clandestinely feed and 
house migrants, have on their spirits and appearances. Beyond shared meals and free showers, these evenings involve dancing, singing, or sitting around a campfire. Marie and Isabelle thus manage to restore a sense of community and of normalcy for these individuals who literally appear to come back to life: "c'était comme un miracle de les voir revivre à ce point" (117). In both texts, the narrators also repeatedly focus on the migrants' faces as if to render them more visible and human. Anne initially struggles to decipher Destiny's "visage"_- "Anne ne sait pas lire le visage de Destiny, un peu, si peu" (52)—but she eventually manages to do so: "Elle a un visage de femme, qu'Anne peut lire" (157). This evolution in how the migrant character is perceived by the nonmigrant protagonist helps restore Destiny's personhood. In short, through these re-humanizing strategies, Adam and Fleutiaux advocate for a recognition of migrant individuals as persons.

While there are clear efforts to bring visibility to the experiences of contemporary illegal migrants on French soil in the works of Adam and Fleutiaux - a noble endeavor in a context where alarming living conditions and overstretched infrastructures are the norm-, we also notice questionable modes of representation that demand attention. Commenting on a shift from "entrenched patterns of postcoloniality" in favor of "writing about "the migrant crisis", since the impact of the war in Afghanistan and Iraq" Anna-Louise Milne stresses that "[a]s an 'elsewhere' from which to think the structural failings of our contemporary societies, the camps and escape routes across the Mediterranean" have become increasingly "compelling" in the last ten years ("Le Regard"). She further explains that works by Gaudé, Fleutiaux, or de Kerangal "are all registers of the fascination that this contemporary form of forced displacement with its extremities of cultural and material encounter has on the literary imaginary" ("Le Regard"). When examining publishing patterns and the notable increase of literary works dealing with the migrant crisis, this fascination is easily quantifiable. However, we argue that this tendency transfers to how non-migrant French authors choose to represent migrants within their texts. Both Adam and Fleutiaux create migrant characters who mesmerize nonmigrant characters. Marie and Anne seem to be held spellbound under the irresistible attraction of the migrant figure who thus takes on a mythical quality and becomes an exoticized, eroticized, and, at times, fetichized passive object of fascination.

In $A$ l'abri de rien and in Destiny, when completing tasks associated with helping migrant characters, Marie and Anne are repeatedly described as being in an uncontrollable frenzy. The care and empathy they extend thus become tainted by fascination. For instance, Fleutiaux explains that "Anne entre alors dans un tunnel d'actions désordonnées, nerveuses" as she attempts to secure 
help for Destiny before leaving on her vacation (57). Likewise, Marie appears to be in a trance and performs her volunteer tasks in a robot-like manner: "Je n'ai pas réfléchi. Je me suis exécutée [...] Je me sentais comme une gamine affolée un jour de rentrée" (63). Marie even admits that, at the end of her shift, she feels sobered up: “j’avoue je me suis sentie presque déçue, comme dégrisée” (64). Anne's and Marie's states of frenzy and uncontrollable urges to perform these caring tasks is also magnified syntactically. Marie's agitation as she takes stock of her assigned tasks- “elle m'a dit de disposer des serviettes en papier, des assiettes creuses, des cuillers des verres d'eau des bouts de pain, des pommes et des yaourts sucrés" (63) - is conveyed by accumulations and missing commas. Anne's own agitation as she is gathering clothes for Destiny in her apartment"Placard des grands-parents [...] Deux ou trois vêtements pour chacun [...] Ici, cintres tassés les uns contre les autres" (18)—is materialized by the buildup of verb-less sentences. This transfixed state is also stressed in the way Marie describes the migrants from head to toe, making the reader feel as if they are staring and scrutinizing the migrants with her (60). What is more, she seems unable to stop herself: "Chaque fois qu'on en croisait un je ralentissais, je ne pouvais pas m'en empêcher" (32), and later, "Je ne pouvais pas m'empêcher de détailler leurs joues crasseuses et creusées"(64). The repetition of "empêcher" points to an attraction that Marie is powerless to control. In Destiny, Anne's fascination with the title character turns possessive. Destiny quickly becomes "sa $a^{6}$ protégée" (8) and "son inconnue" (13 and 15). Within the first few pages of the récit Anne even describes her relationship with Destiny as mutually codependent: "L'inconnue lui appartenait. Ou elle lui appartenait. Comme si quelqu'un avait dit: 'Vous vous appartenez, elle et toi"' (8). Anne is fascinated and attracted by the ownership she feels over Destiny, going so far as to describe herself as a predator hunting her prey (8). In both works, the migrants have no say over this treatment, a state mirrored by the women's own helplessness over their fascination.

The attraction Marie and Anne experience goes hand in hand with a tendency to represent the migrant characters as mythical figures. They are described with superhuman qualities, directly contrasting with their terrible physical and mental wounds. Anne perceives Destiny as powerful—“c'est le corps massif de Destiny, ses jambes solides, la puissance brutale qu'elles peuvent développer" (158) — and indestructible_- "cette femme est si forte que rien ne peut la détruire" (132). Her strength is more than physical: "Anne croit que l'esprit de Destiny est indomptable" (107). Marie sees this same force of spirit in the migrants she encounters, particularly in Drago: "il semblait bourré de vie, de sang, d'énergie, d'avenir, on lui aurait donné les clés du monde” (92). Adam and

${ }^{6}$ Our emphasis.

${ }^{7}$ Our emphasis. 
Fleutiaux both convey the characteristic of strength through animal imagery. Destiny is said to resemble "un taureau" (101), "une lionne" (144), and "la tigresse" (158) while Bechir has "son regard d'aigle" (66). These superhuman and animalistic qualities are complemented by the magic aura that surrounds the migrants. In À l'abri de rien, Marie is mesmerized by Bechir's dance in the garden. The silence from the audience, the sound of the wind and the birds, and the flames of the campfire in the cold air leave her remarking that the performance "était comme un rituel étrange ses mains tendues vers le ciel" (138). In Destiny, Anne is witness to, and becomes obsessed by, her protégé's "regard de Méduse" (32)—also referred to as a "regard brûlant et féroce" (176), a "foudre qui peut jaillir de ses yeux" (105), or a "regard de feu" (166)—to which Anne confers magic-like qualities as she is convinced that it helped Destiny fend off abusers throughout her migration journey. Finally, Anne and Marie themselves take on mythical roles highlighted by biblical imagery. During her first day working in the tent, Marie washes Drago's feet after he walked barefoot for miles to reach help (72). The act is reminiscent of Jesus humbly washing his disciples' feet the night before his crucifixion. Anne functions comparably when Destiny is in the hospital after giving birth to her daughter: "Anne aimerait jouer les Rois mages pour Destiny et son enfant" (44). She brings gifts in order to "rendre hommage à l'enfant" (43), effectively turning herself into one of the Three Kings and Destiny into the Virgin Mary. This use of biblical imagery contributes to portraying the non-migrant character as a savior of sorts who celebrates the disciple- or Christ-like migrant figure who receives their assistance.

Contrary to the re-humanizing strategies analyzed above, Destiny and the migrant characters in '̀ l'abri de rien are also repeatedly objectified. Anne's perception of her protégé's psyche is expressed in concrete terms and lacks psychological depth: "Anne la perçoit comme un être compact, d'un bloc, un monolithe" (49). In both texts, this objectification often takes on exoticizing, eroticizing, or, in Destiny's case, fetishizing tones. Graham Huggan in The Postcolonial Exotic: Marketing the Margins explains that "exoticism" is "conventionally [defined] as an aestheticising process through which the cultural other is translated" (ix). He adds that "the exotic is not, as is often supposed, an inherent quality to be found 'in' certain people, distinctive objects, or specific places; exoticism describes, rather, a particular mode of aesthetic perception-one which renders people, objects, and places strange even as it domesticates them, and which effectively manufactures otherness" (13). We notice many instances where migrant characters are rendered "strange" in Destiny and in $A$ l'abri de rien. For instance, Anne stresses that Destiny "cause la sensation d'étrangeté" (169) and comments on the "impression ethnique" Destiny's body produces on her (51). Furthermore, not only is Destiny repeatedly associated with a djinn figure- "spirits that according to Muslim demonology inhabit the earth, assume 
various forms, and exercise supernatural power" (“djinni”)—, that of Aziza (65 or 80 ), she is also compared to Saartjie Baartman. During the $19^{\text {th }}$ century, this South African woman was "[b]rought to Europe [...] stage-named the 'Hottentot Venus' [...] [and] paraded around 'freak shows' in London and Paris, with crowds invited to look at her large buttocks" (Parkinson). While it could be argued that this comparison is meant to denounce the treatment of African women's bodies in postcolonial contexts, Anne's account of Destiny's shape when Baartman is conjured up is highly problematic: "Volumes de chair compacte distribués violemment sur une stature ramassée. Croupe et cuisses fortes, buste large, formant deux pôles puissants autour de l'étranglement de la taille" (50). Because it highlights the generous proportions of her buttocks, thighs, and chest, such a representation of Destiny's body perpetuates stereotypical visions of the African woman's figure. This focus on the body appears to be characteristic of how Anne and Marie see migrant characters.

Migrant bodies become eroticized when the otherness of their appearance is highlighted. For instance, Marie's gaze over Bechir registers "son regard caramel" (138) and "ces grands yeux soulignés au khôl" (141), thus both exoticizing and eroticizing his body by relying on stereotypical Middle Eastern beauty standards. Bechir is also eroticized during two desire-charged encounters with Marie when she rests her head on his shoulder as they dance "collés" (141) or when they share an intimate night cuddling under blankets in an abandoned beach hut (182). In Destiny especially, the migrant character's objectification borderlines fetishization. Just as with a fetish, Anne "believe[s]" Destiny has "magical power to protect or aid its owner" ("fetish"). Anne describes Destiny as " $s a^{8}$ garante, $s o n$ " sésame" (163). She also perceives her as having "un pouvoir tellurique" (80) and nicknames her "l'Inentamée" (37) when describing her epic battling with the sea during her Mediterranean crossing. Finally, when Anne highlights that "Si [Destiny] se perd, je me perds et le monde se perd," she clearly endows her with the fetish-like power of healing, not only for Anne herself but for the world (182). This insistence on Destiny's psychic abilities points to how Anne envisions her as entirely other. As Elizabeth Anker notes, such accounts "dramatiz[ing] the plea of radical Otherness for inclusion or recognition[,]" involve a "concentration on alterity [that] has at times produced a fetishization of that condition and a sublime fascination with victimization" (12). In a similar vein, Huggan explains that exoticising tendencies "denot[e] an expanded, if inevitably distorted, comprehension of diversity" (14). This leads us to pause and consider the status of the diverse and marginalized migrant figures in the two texts under study. The questionable modes of representation we highlighted magnify the imbalance in the power relations that are featured in Adam's and

8 Our emphasis.

${ }^{9}$ Our emphasis. 
Fleutiaux's works. When examining how Anne and Marie perceive Destiny or Bechir, these migrant characters become further marginalized to the point where the reader, in turn, may view them as commodities in the non-migrant characters' lives.

As Adam and Fleutiaux explore migrant trajectories in their texts, the white female protagonists take the forefront. Their mental states play crucial roles in their relationships with the migrants and, ultimately, become more important for Marie and Anne. In À l'abri de rien, Marie has been struggling for a long time with her "angoisse[]," which she describes "me bouffait le ventre et la poitrine sans que je sache pourquoi" (20). From the beginning of the novel, the reader can clearly follow her downward spiral as her mental health issues affect every part of her life. Marie does not sleep, does not eat, forgets her daughter's birthday (168), runs away from home to a cave in the woods twice (149 and 216), and even eats dirt (52). She feels an inescapable desire to disappear"Cette sensation de tomber en poussière soudain, de devenir liquide et de disparaître, d'être comme mangée de l'intérieur, tordue, mâchée, étranglée, essorée, vidée" (78) —and is overcome by her own emptiness, feverishly repeating the word "rien" $(64,70,119,138$, and 215) and stressing that "rien n'avait de sens" (53). Helping the migrant characters gives Marie some sense of purpose and, when that is taken from her, she completely breaks down: "Après j'ai sombré complètement, plongé dans des eaux noires, des sables opaques [...] Après ça j'étais en pièce et ma vie aussi' (201). Adam's text ends with Marie in a mental institution, hopeful, but uncertain as to when she will see her family again.

In Destiny, Anne's mental health issues are much less explicit, but they are just as important to the récit. Anne indicates that she does not know who she is"Et elle, qui est-elle? Deux ou trois entités" (49)—and regularly references "sa multitude[,]" internal voices that inhabit her mind and influence many of her decisions, often conflictingly (9, 37, 134, and 149). This inner struggle is, according to Elizabeth Sercombe, characteristic of Fleutiaux's female protagonists who are "frequently challenged by inner tensions and conflicts" (3). Anne herself recognizes that her mental state is compromised: "Vraiment elle aurait besoin à son tour d'un soutien psychologique, ça ne va pas du tout dans sa tête, lui disent toutes celles et ceux qu'elles abritent" (145). She also develops strange maternal instincts towards Destiny. She views herself as her mother and wants to fill the role of "bienfaitrice" for Glory (60) and "tante bienveillante" for Destiny's husband (129). Anne compares Destiny to her newborn granddaughter: "Elle voit dans les yeux de Destiny la même attente avide que dans ceux de sa petite-fille" (147). Finally, Anne even sees herself in Destiny's place as a migrant: "Les gens sur ces barques ne sont pas des anonymes. S’ils ne 
sont pas Destiny, ils pourraient l'être, ils pourraient être son frère, sa mère, ses enfants. Ils pourraient être elle-même, Anne" (110). Marie experiences similar identification with the migrants' condition as her degrading mental health leads her to mirror their state of despair: she loses her possessions, her family, and her money, she sleeps outside, stops eating, and is assaulted (195). This identification, because it involves the non-migrant character having "an affective and effective understanding" of the migrant experience, may be read as the ultimate empathy (Panaite 107). However, it is problematic in that it robs the migrant characters of the uniqueness of their condition and shifts the focus from them to Marie's and Anne's mental wellbeing.

Not only do Marie's and Anne's mental states overshadow the migrant stories constituting the premise of each literary work, the modes of narration also distract from the migrant focus and do not provide narrative agency for the migrant characters. Both Adam's and Fleutiaux's texts are filtered through the perception of Marie and Anne whose thoughts the reader has access to. Even if A l'abri de rien is recounted in first-person narration while Destiny features thirdperson narration, the reader is similarly immersed in the non-migrant protagonist's thought process throughout her interactions with the migrant(s) she is caring for. There is no choice but to rely on Marie's and Anne's descriptions of their protégés' lives and it is therefore particularly problematic that the two women are presented as unreliable narrators. In Ál'abri de rien, the first words of the novel — which are repeated verbatim further into the textset the tone: "Comment ça a commencé? Comme ça je suppose" (11 and 34). Similarly, the question "Combien de temps ça a duré?" echoes throughout the novel and reinforces the shakiness of Marie's remembering (125 and 213). She goes as far as to question the veracity of the facts she presents: "Je ne sais plus et ça n'a pas d'importance" (13). Anne's accounts in Destiny present her as being in control of the version of the facts she chooses to relay. Her power over Destiny's story is vividly materialized by a knitting metaphor which presents her as adding and removing stitches as she constructs Destiny's trajectory: “C'est une nouvelle maille dans le récit qu'elle tricote de sa vie [Destiny's], à chaque rencontre en ajoutant une autre qui complète ou défait le rang précédent ou l'oriente dans une autre direction" (90). Furthermore, Anne repeatedly opts for the interpretation of Destiny's life events that is the least traumatic for her: "Anne se déroule la fiction qui la rassure" (29) or "Anne entendra plutôt la deuxième interprétation" (137). The unreliability of the non-migrant protagonist's recounting is even highlighted within the text: "le diaporama d'Anne est erroné, elle fabule" (101). In Á l'abri de rien and in Destiny, migrants' voices are repressed. When Marie and Anne are in the presence of migrant characters, we notice exceedingly rare instances of direct speech sentences allowing brief access to the migrants' voices. For instance, Destiny states: "I am 
not afraid" (166) and Bechir explains: "Ma femme et mes filles sont en Angleterre" (160). Otherwise, only indirect speech versions of the migrants' accounts, filtered through Marie and Anne, are provided. Consequently, the reader is kept in the dark as far as what happens to the migrant characters outside of their encounters with the non-migrant protagonists.

In Mobilités d'Afrique en Europe. Récits et figures de l'aventure, Catherine Mazauric broaches the topic of representation and reflects on the consequences of " "parler pour' les victimes des politiques étatiques meurtrières de fermeture des frontières, voire 'devenir eux"' (334). She devotes most of her attention to Coulin's Samba pour la France in which the narrating " $\mathrm{je}$ " is alternately that of the migrant character and that of a female NGO volunteer. Mazauric explains that, thanks to this shared narrative voice, the author successfully "réfracte dans la fiction sa propre position de témoin engagé, tout en se défendant par ailleurs d'avoir voulu 'témoigner" and rejects "une illusoire fusion" thus providing "une place pour chacun dans une lutte commune" (334-35). In contrast, the narrative choices in A l'abri de rien and in Destiny fail to confer any sense of agency to the migrants' voices and confirm the objectification of their individualities, becoming plot twists in Marie's and Anne's own stories. The endings of the two works magnify the importance of Marie's and Anne's agency against that of the migrant characters. The last twenty-two pages in Ál'abri de rien are focused on Marie's recounting of her final mental breakdown all the way to her hospitalization with only twelve lines devoted to the fate of the local migrants after the closure of all helping structures (217). Destiny's ending describes Anne's unrealistic imaginary prediction of the future of her protégé's children. Michael becomes a famous footballer and Kelvin a pilot who assists his sister Glory, a boat captain, in migrant rescue missions. Anne also imagines that Glory and her granddaughter, who have never met, become "amie(s) de cœur" (184). This ideal ending, which evokes a certain immaturity usually associated with romance or adolescent novels, is in sharp contrast with the last account of Destiny's situation who, although she received a 4-month work permit, is struggling to feed her family (172) and is in need of surgery (180). With Gayatri Chakravorty Spivak's famous "Can the Subaltern Speak?" piece in mind-where she highlights the pitfalls of any attempt by western intellectuals to "represent (speak for) the oppressed groups" (275)—we argue that Adam and Fleutiaux's empathic drive is compromised by the narrative repression and objectification of the migrant voices within their texts. Marie's and Anne's unreliability as well as their overtaking of the texts' migrant plot all point to an appropriation of migrant victimhood and of marginality for the good of the non-migrant character. 
This appropriation is most blatant when examining some of the self-serving motives behind the altruism of Adam's and Fleutiaux's protagonists. Helping the migrants allows Marie to alleviate some of her mental health issues. As she volunteers, she gains strength—“ils reprenaient courage et moi aussi” (117)— to the point where she feels invincible: "je pensais à la soirée qui venait de se passer, [...] et rien ne pouvait m'anéantir" (119). Even her outlook on the banality of her domestic life evolves. Before meeting migrants, she was completely unable to take care of her home_- “j'étais incapable de rien faire. J'ai tout laissé en plan" (59)—but after finding purpose through volunteering, she describes cleaning as "si facile et presque joyeux" (127). Both Marie and Anne become centered and grounded. Marie relates how she feels "entière et à $[\mathrm{s}]$ a place pour une fois, entière et à [s]a place comme jamais" during the evenings she shares with Isabelle and the migrants (129-30). Anne repeatedly insists on the importance of her service. She expects others to show "respect pour cette œuvre" which she deems "exceptionnelle" (15). The protagonists also look for rewards for their efforts. Marie takes Isabelle's praise after she agrees to help illegally host migrants "comme un cadeau" (98). Anne appropriates Destiny's successes and uses them as self-rewards: "Les réussites de Destiny sont pour elle comme des bonbons, à sucer quand l'envie lui en vient" (72). They also compensate for feelings of betrayal. Anne experiences guilt because she fears she may have made Destiny more visible to French authorities by calling for help when she had her breakdown (82). Marie's guilt is linked to the role she likely played in the police raid of Isabelle's house (167). Additionally, Anne uses Destiny as a reason not to help other individuals in need, as if giving to one migrant were equivalent to giving to them all. When she passes another migrant or homeless person, Anne "pense à Destiny" (151) and "[p]ensant à Destiny toujours, elle ne donne rien à ce mendiant inconnu, ce mendiant anonyme. Mieux vaut garder ses pièces pour Destiny" (153). Marie and Anne are therefore not helping the migrant characters selflessly, but as a way to find a reprieve from their mental states and to feel gratified for their caring actions.

In the case of Fleutiaux's text, the manner in which the non-migrant protagonist measures the success of the migrant character is problematic. Even though Destiny hits major milestones such as being reunited with her children or entering collective protest against her exploitative employer, Anne-until the contrasting idealistic ending described above-usually appears to be displeased with Destiny's progress. Her desire for Destiny is to have a normal life in line with her French standards of what constitutes normality: "Tout ce qui rapproche Destiny de la normalité de la vie, de la normalité d'une vie ici en France, soulage profondément Anne, la rend heureuse" (27). Understandably, Anne is adamant that Destiny's success depends on her becoming educated and is most proud when her protégé signs up for French language classes- “[i]ntense satisfaction 
d'Anne" (141)—or arranges to meet Anne at a library— “[r]encontrer Destiny et sa famille dans une bibliothèque fait énormément de bien à Anne" (170). When Destiny is granted custody of her children and has no choice but to drop out of her French classes to care for them, Anne's reaction is extreme: "Anne vit cet abandon de l'école, cet abandon des cours du soir, comme une défaite" (144). Here, she clearly lacks empathy for Destiny's practical circumstances. Anne's focus is on Destiny' potential for intellectual success rather than on family or logistical victories.

There are indeed clear limits to Marie and Anne's altruism. Marie admits that she is unable to verbalize why she is helping- "si on m'avait posé la question, je n'aurais pas su répondre" (86)—and even confides that she is not sure she actually cares about the fate of the migrants she serves- "Qu'est-ce que j'en avais à foutre de tous ces types au fond? Peut-être rien. Peut-être. Je ne sais pas" (138). Anne confesses that she could do a lot more to help Destiny (151) but that she is unable to absorb more of her trauma: "La vérité, c'est qu'elle ne peut prendre en elle davantage de la nébuleuse Destiny" (170). Anne even forgets to check in on Destiny during her vacation by the sea, in a place where "les gens comme Destiny n'existent pas" (59), and guiltily shares that "[e]lle a fait une promesse, et elle n'a pas tenu cette promesse" (58). Marie's and Anne's empathic drives therefore repeatedly reach a dead-end, leaving the reader at a loss to understand the true motives behind their actions and to process their occasional selfishness. Finally, if we consider Marie and Anne-female characters with traditional French first names-as representing France, the two women's ambivalent feelings toward the caring mission they embraced can be interpreted as a general criticism toward France's treatment of migrants today. Just as Marie and Anne wrestle with ambivalent altruistic feelings, France pains to reconcile its humanistic ideals with its tough stance when it comes to handling the consequences of the migrant crisis.

In a global context that has been "widely touted as the era of human rights[,]" literary accounts of illegal migration by non-migrant authors provide us with an opportunity to examine how the humanist ideals of Western intellectuals engage with their self-given mission of representing these displaced individuals (Anker 1). As we conclude this study, it is important to consider the ethical ramifications of Adam's and Fleutiaux's representations of migrant stories. On the one hand, we have shown that these authors successfully create an empathic discourse of care that individualizes and humanizes illegal migrants while openly criticizing their treatment by French institutions. The two works under study take on the challenging task of representing the fate of illegal migrants in France today, thus bringing their existence to light and educating the reader on their complicated trajectories. The authors construct a laudable desire to help and to make up for 
the shortcomings of French society, prompting the reader to reflect on how to best help those in need and on whether or not it is possible to attain a pure form of altruism. On the other hand, we have stressed the ambivalent nature of this empathic drive. The modes of representation adopted by Adam and Fleutiaux objectify migrant characters and deprive them of any textual autonomy. Whether or not the authors' dehumanization of the characters is intended as a criticism of their status in French society, plot-wise and narratively, because there is little effort to give Destiny, Drago, Bechir, or Jallal any agency, they become accessories in the lives of caregivers whose altruistic motives are ethically problematic. Marie and Anne's thirst for mental stability, purpose, validation, and rewards compromises the legitimacy of their social justice warrior status.

Considering the need for an understanding of ethics as demanding "radical Otherness for forgiveness, hospitality, and sociopolitical inclusion," we contend that Adam and Fleutiaux's problematic empathy fails to be truly welcoming of otherness (Anker 8). In fact, Jacques Derrida underlines that "la loi de l'hospitalité [...] commanderait d'offrir à l'arrivant un accueil sans condition” (71). Because of Marie and Anne's tendency to objectify their protégés and because of the, at times, self-serving nature of their altruism, migrant victimhood and marginality are appropriated in À l'abri de rien and in Destiny. Such literary exploitation of marginal migrant trajectories has been exposed by several scholars. Subha Xavier notes that the migrant text "deals in an exoticism that is exploited for the sake of the literary marketplace" and that the "authors of migrant texts [...] walk the fine line between exploitation and resistance" (69). Likewise, Sabo shows that "[m]igrant literature in the new millennium is at once a cultural artifact, a commodity, and a tool for political engagement" (162). These two scholars stress a similar ambivalence as the one we brought to light in Adam's and Fleutiaux's works. In today's literary marketplace, because "narratives of clandestine migration" constitute a "lucrative subgenre[,]" the social justice drive of authors attempting to speak for migrants can be negatively impacted by their tendencies to commodify contemporary migrancy (Sabo 163).

While this ambivalence may seem to lead to an ethical dead-end as far as the ability of non-migrant authors to write about illegal migration, especially as "the authentic migrant experience $[\ldots]$ is one that comes to us constructed by hegemonic voices" (Gunew 61), alternative modes of representation that would alleviate some of these commodification dilemmas could be explored by these authors. For instance, granting the migrant character a greater importance in the plot, making their voice more narratively central, or avoiding objectifying tendencies would contribute to boosting their agency. Still, given the ethical limitations inherent to the hegemonic position of the non-migrant author 
portraying the fate of the marginalized, it seems difficult to produce an authentic voicing of the migrant experience. This elusive authenticity is best tackled thanks to projects like "University for all," an initiative which consisted in gathering life stories authored by migrants of the Jungle and which ultimately led to the publication of the collection Voices from the "Jungle": Stories from the Calais Refugee Camp (Godin et al.). Although still mediated by editors and the literary marketplace, such efforts manage to give the individual affected by today's migrant crisis more control over the ways their stories are shared globally. 


\section{Bibliography}

Achille, Étienne. “"Entendez-vous dans nos campagnes': Écrivains blancs et France postcoloniale." Francosphères, vol. 7, no. 1, 2018, pp. 15-28.

Adam, Olivier, et al. Bienvenue !: 34 auteurs pour les réfugiés. Points, 2015.

---. À l'abri de rien. Éditions de l'Olivier, 2007.

---. Passer l'hiver. Éditions de l'Olivier, 2004.

---. Je vais bien ne t'en fais pas. Paris, Le Dilettante, 2000.

Anker, Elizabeth S. Fictions of Dignity: Embodying Human Rights in World Literature. Cornell University Press, 2012.

Bessy, Marianne, and Catherine Khordoc. "Introduction: Plaidoyer pour l'analyse des pratiques scripturales de la migrance dans les littératures contemporaines en français." Nouvelles Études Francophones, vol. 27 no. 1, 2012, pp. 1-18.

Bloch, Hannah. "That Little Syrian Boy: Here's Who He Was." NPR, 3 Sept. 2015, www.npr.org/sections/parallels/2015/09/03/437132793/ photo-of-dead-3-year-old-syrian-refugee-breaks-hearts-around-theworld. Accessed 13 June 2019.

Boghani, Priyanka. “The 'Human Cost' of The EU's Response to the Refugee Crisis.” PBS, 23 Jan. 2018, www.pbs.org/wgbh/frontline/article/the-humancost-of-the-eus-response-to-the-refugee-crisis. Accessed 13 June 2019.

Boris, Hugo. Police. Grasset, 2016.

Bris, Michel le, et al. "Pour une 'littérature-monde' en français." Le Monde des Livres, 16 March 2007, pp. 1-3.

Busnel, François. "Olivier Adam: 'On se ment beaucoup à soi-même.” LExpress.fr, 28 Aug. 2012, www.lexpress.fr/culture/livre/olivier-adamon-se-ment-beaucoup-a-soi-meme_1153041.html. Accessed 6 June 2019.

"Calais Migrant Camps: Seventeen Years of Shanty Towns." Channel 4, 30 Jul. 2015, www.channel4 .com/news/the-first-calais-migrant-camp-fifteenyears-of-shanty-towns. Accessed 13 June 2019.

Collins, Lauren. "Europe's Child-Refugee Crisis." The New Yorker, 19 Feb. 2017, www.newyorker.com/magazine/2017/02/27/europes-child-refugeecrisis. Accessed 13 June 2019.

Coulin, Delphine. Samba pour la France. Seuil, 2011.

Fleutiaux, Pierrette. Destiny. Actes Sud, 2016.

Derrida, Jacques and Anne Dufourmantelle. De l'hospitalité. Calmann-Levy, 1997.

"Djinni." Merriam-Webster. www.merriam-webster.com/dictionary/djinn. Accessed 17 July 2019.

Edwards, Norrell. "The Right to Paris: Migrants' Narratives in Shay Youngblood's Black Girl in Paris and Évelyne Trouillot's La mémoire aux 
abois." Paris and the Marginalized Author: Treachery, Alienation, Queerness, and Exile, edited by Valérie K. Orlando and Pamela A. Pears, Lexington Books, 2019, pp. 125-38.

Énard, Mathias. Rue des voleurs. Actes Sud, 2012.

"Entretien avec Pierrette Fleutiaux." France 3 Limousin, 14 May 2016, france3regions. francetvinfo.fr/nouvelle-aquitaine/le-limousin-tire-lacouverture-lui-995853.html. Accessed 27 June 2019.

"Europe's Migrant Crisis Explained." The Wall Street Journal, 10 Sept. 2015, www.wsj.com/video/europe-migrant-crisis-explained/A8A639CB664D-4FD2-8186-00CDECBCB8DC.html. Accessed 13 June 2019.

"Fetish." Merriam-Webster. www.merriam-webster.com/dictionary/fetish. Accessed 17 July 2019.

Fleutiaux, Pierrette. Destiny. Actes Sud, 2016.

---. Nous sommes éternels. Gallimard, 1990.

---. Métamorphoses de la reine. Gallimard, 1984.

Gaudé, Laurent. Eldorado. Arles, Actes Sud, 2006.

Gefen, Alexandre. Réparer le monde: la littérature française face au XXI siècle. Éditions Corti, 2017.

Geniès, Bernard. "Pierrette Fleutiaux, disparition d'une éternelle.” L'Obs, 28 Feb. 2019, www.bibliobs.nouvelobs.com/actualites/20190228. OBS0995/pierrette-fleutiaux-disparition-d-une-eternelle.html. Accessed 6 June 2019.

Godin, Marie, Katrine Møller Hansen, Aura Lounasmaa, Corinne Squire, and Tahir Zaman, editors. Voices from the "Iungle": Stories from the Calais Refugee Camp. Pluto Press, 2017.

Gunew, Sneja and Gayatri Chakravorty Spivak. "Questions of MultiCulturalism." The Postcolonial Critic: Interviews, Strategies, Dialogues, edited by Sarah Harasym, Routledge, 1990, pp. 59-66.

Hartman, Geoffrey H. "Maurice Blanchot: Philosopher-Novelist." Chicago Review, vol. 15, no. 2, 1961, pp. 1-18.

Heudré, Denis. Bleu naufrage: élégie de Lampedusa. La Sirène étoilée, 2015.

Heurtier, Annelise. Refuges. Casterman, 2015.

Huggan, Graham. The Postcolonial Exotic: Marketing the Margins. Routledge, 2001. Je vais bien ne t'en fais pas. Directed by Philippe Lioret, performances by Mélanie Laurent, Kad Mérad and Isabelle Renaud, Nord-Ouest Films, 2006.

Just, Daniel. "The Politics of the Novel and Maurice Blanchot's Theory of the Récit, 1954-1964.” French Forum, vol. 33, no. 1-2, 2008, pp. 121-39.

Keen, Susan. Empathy in the Novel. Oxford University Press, 2010.

Kerangal, Maylis de. à ce stade de la nuit. Verticales, 2015.

Larminat, Astrid de. "Disparition de la romancière Pierrette Fleutiaux à 78 ans.” Le Figaro, 28 Feb. 2019, www.lefigaro.fr/livres/2019/02/28/03005-20190228ARTFIG00256- 
disparition-de-1-ecrivaine-pierrette-fleutiaux-a-78ans.php. Accessed 6 June 2019.

Lionnet, Françoise. "Universalisms and francophonies." International Journal of Francophone Studies, vol. 12, no. 2-3, 2009, pp. 203-21.

Louviot, Myriam. "Postcolonial Writing in France Before and Beyond the 2007 Littérature-monde Manifesto." CLCWeb: Comparative Literature and Culture, vol. 18, no. 4, 2016, pp. 2-8.

Maman est folle. Directed by Jean-Pierre Améris, performances by Isabelle Carré, Marc Citti, and Nazmi Kirik, Escazal Films, 2007.

Mardorossian, Carine M. "From Literature of Exile to Migrant Literature." Modern Language Studies, vol. 32, no. 2, 2002, pp. 15-33.

Mazauric, Catherine. Mobilités d'Afrique en Europe. Récits et figures de l'aventure. Karthala, 2012.

"Migrant Crisis: Migration to Europe Explained in Seven Charts." BBC, 4 March 2016, www.bbc.com/news/world-europe-34131911. Accessed 13 June 2019.

Mijola, Camille. "Remembering Pierrette Fleutiaux, French Novelist Who Explored Intimacy and the Immigrant Experience." The Independent, 23 March 2019, www.independent.co.uk/news/obituaries/pierrettefleutiaux-death-novelist- french- literature-destiny-a8823681.html. Accessed 6 June 2019.

Milne, Anna-Louise. "Le Regard de l'étranger? France as elsewhere: un échange à partir de six Questions." Revue Critique de Fixxion Française Contemporaine/Critical Review of Contemporary French Fixxion, vol. 16, 2018, pp. 179-90. www.revue-critique-de-fixxion-francaise-contemporaine .org/rcffc/article/view/fx16.18/1255. Accessed 15 July 2019.

Ming, Ye. "Lampedusa Shipwreck: From the Depths of the Mediterranean Sea." Time, 18 Nov. 2014, www.time.com/3594604/lampedusashipwreck-from-the-depths-of-the-mediterranean-sea/. Accessed 14 June 2019.

Nossiter, Adam, and Tyler Hicks. “Inside France’s 'Jungle’: Desperate Keep Coming to Calais." The New York Times, 26 Sept. 2016, www.nytimes.com/2016/09/27/world/europe/calais-jungle-francemigrants.html?module=inline. Accessed 13 June 2019.

Panaité, Oana. The Colonial Fortune in Contemporary Fiction in French. Liverpool University Press, 2017.

Parkinson, Justin. "The Significance of Sarah Baartman.” BBC, 7 Jan. 2016, www.bbc.com/news/magazine-35240987. Accessed 17 July 2019.

Pruteanu, Simona E. L'Écriture migrante en France et au Québec (1985-2006): Une analyse comparative. Lincom, 2013.

Redonnet, Marie. Diego. Éditions de Minuit, 2005. 
Reinisch, Jessica. "Forever Temporary': Migrants in Calais, Then and Now." The Political Quarterly, vol. 86, no. 4, 2015, pp. 515-22.

Sabo, Oana. The Migrant Canon in Twenty-First-Century France. University of Nebraska Press, 2018.

Schmitt, Éric-Emmanuel. Ulysse from Bagdad. Albin Michel, 2008.

Sercombe, Elizabeth. Strange Adventures: Women's Individuation in the Works of Pierrette Fleutiaux. Peter Lang, 2016.

Spivak, Gayatri Chakravorty. "Can the Subaltern Speak?" Marxism and the Interpretation of Culture, edited by Cary Nelson and Lawrence Grossberg, Macmillan, 1988, pp. 271-313.

Thomas, Dominic. "Fortress Europe: Identity, Race and Surveillance." International Journal of Francophone Studies, vol. 17, no. 3-4, 2014, pp. 44568.

Walkowitz, Rebecca L. "The Location of Literature: The Transnational Book and the Migrant Writer." Contemporary Literature, vol. 47, no. 4, 2006, pp. 527-45.

Welcome. Directed by Philipe Lioret, performances by Vincent Lindon, Firat Ayverdi, and Audrey Dana, Nord-Ouest Production, 2009.

Xavier, Subha. The Migrant Text: Making and Marketing a Global French Literature. McGill-Queen's University Press, 2016.

Zalberg, Carole. Fen pour feu. Actes Sud, 2014. 